\title{
Small Companies Innovations in Emerging Countries: E-Business Adoption and its Business Model
}

\author{
Silvia Novaes Zilber', José Braz de Araújo²
}

\begin{abstract}
Organizations have been taking advantage of e-business as an innovative opportunity to improve business results, but small companies have not been adopting this tool as quickly as large corporations. There are several studies on the adoption of e-business in developed countries, but there are fewer studies in emerging Latin American countries. Thus, the goal of this study was to describe the business model of small companies that have adopted e-business (an innovation to this segment) in an emerging Latin American country. For that, we used a quantitative approach trough a survey data. Main results: the owners/shareholders play a central role in making decisions about the adoption of e-business; the main value delivered from using the internet was improved brand and/or product awareness. The companies using e-business achieved increase in business and an expanded geographic scope of sales. The main difficulties encountered were training personnel to work on the internet and defining which web activities can lead to achieve strategic objectives.
\end{abstract}

Keywords: innovation; e-business; small companies; emerging country; business model

'PhD in Business Administration, professor and researcher at UNINOVE University, electric engineer from POLI/USP, PhD in Business Administration from FEA/USP. Fields of research: Strategy and Innovation. Department of Business Administration - PMDA UNINOVE University.Address: Av Francisco Matarazzo, 612, bloco C, 2o andar. São Paulo - SP - Brazil. Zip code: 0500 I-100. Brazil. Phone: 55 II 36659342. Cel phone: 55 II 96582202. E-mail: silviazilber@gmail.com

${ }^{2} \mathrm{MsC}$ in Business Administration; PhD student at UNINOVE University. Department of Business Administration - PMDA UNINOVE University. Address: Av Francisco Matarazzo, 612, bloco C, 2o andar. São Paulo - SP - Brazil. Zip code: 0500 I- 100. Brazil. Phone: 55 II 36659342. E-mail: jbraz@ig.com.br

ISSN: 07 I 8-2724. (http://www.jotmi.org)

Journal of Technology Management \& Innovation () Universidad Alberto Hurtado, Facultad de Economía y Negocios. 


\section{Introduction}

Small and micro-sized companies are a relevant sector of the economy in emerging countries, including Brazil, where they account for $98 \%$ of all companies, employ $67 \%$ of the work force, and represent $20 \%$ of Brazil's GDP according to The Brazilian Micro and Small Business Support Service (SEBRAE, 2005). These numbers (i.e., the number of companies versus the percentage of the GDP that they represent) show that the productivity of these companies is relatively small in this emerging Latin American country. These companies may improve their productivity by adopting practices and innovations that enhance organizational performance, such as e-business, which is a low-cost tool that offers many advantages including greater geographic reach, greater visibility for the companies' products, improved relationships with customers and suppliers, and new channels of communication.

It is important to note that small companies are not simply large firms in a smaller size; their characteristics are very different than the characteristics of large companies. As explained by Moraes and Escrivão Filho (2006), various authors have delineated several characteristics of small businesses: they are usually family-based; they rarely hire specialized administration, although the level of organizational maturity is low; they do not have economies of scale, among others.

Considering the characteristics listed above, e-business would appear to be an appropriate tool for small businesses to improve strategic results. Because virtual activities do not require a large number of people and the required initial investment is low, businesses have an opportunity to act in this new field.

There are many studies on the adoption of e-business, which is an organizational innovation, but there are fewer studies on small business that adopt this tool. Kartiwi and MacGregor (2007, p.35) note that "SMEs are not adopting e-commerce with the same speed as their larger counterparts." Furthermore, most of the studies that do exist focus primarily on developed countries. According to Kapurubandara $(2009$, p.I), "the few available studies related to SMEs in developing countries reveal a delay or failure on the part of SMEs to adopt ICT and e-commerce technologies." According to Mishra (2010, p.252), "the increasing internet diffusion has made e-business a huge potential in developing countries."

According to Kalakota and Robinson (2002), e-business is a complex fusion of commercial processes, business applications, and organizational structures for the purpose of creating a high-performance business model. Because of changes in the way that businesses organize their activities after adopting e-business, different strategic guidelines suggest the adoption of e-business as an organizational innovation for small businesses to sell goods and services in a wider geographic area and improve relationships with clients.

The Oslo Manual (OECD, 2005, p.6I) defines the term "organizational innovation" as actions that introduce significantly different organizational structures, implement advanced management techniques, or establish new or substantially changed strategic directions, noting that "an organizational innovation is the implementation of a new organizational method in the company's business practices, workplace organization, or external relations." This definition is suitable for the purposes of this study, which seeks to describe the business model of small enterprises that adopt e-business. E-business is a new organizational method because it requires an appropriate organizational structure to operate. It also reallocates authority and responsibility, and it involves a new workplace organization because companies that already conduct activities in the physical world will also have to meet demands from the virtual world.

Understanding how small businesses use the internet is important because the adoption of e-business solutions gives companies new opportunities to generate income by expanding into new markets and developing new products and services (WADE, JOHNSTON and McCLEAN, 2004). As noted by Högg et al. (2006), online services have had a growing impact on companies because they promote new business models and influence existing ones.

For success in virtual business, strategies, structures, and systems should all be aligned (LAWLER, 1996). Frequently, companies use strategies that are not adequately in line with their structures and systems, which results in low performance during the e-business implementation phase (EPSTEIN, 2000). An integrated strategy should direct the required investments to develop the necessary infrastructure, not only for information systems but also for the human resources and processes that are required to support virtual operation. It is therefore necessary to evaluate the existing resources and the new requirements. In these circumstances, a business model that can guide the development of an enterprise architecture that will deliver value is relevant. The concept of a business model is broader than that of an ebusiness model. Whereas the objectives of a business model are to create value for clients, sell products and services, and convert sales into profits (TEECE, 2009), the objectives of an e-business model are to identify how enterprises can benefit from using the internet as a primary or secondary channel for marketing products (DEITEL, 2004). Additionally, the concept of a business model includes the business as a whole and the architecture necessary to deliver not only the activities in the digital environment but also value. 
In this context, the objective of the present study was to describe a business model for small enterprises that adopt e-business in the goods and services sectors of an emerging country, with a specific focus on the case of Brazil. This adoption of e-business is understood as an organizational innovation. We observe the difficulties and results of adopting e-business in these companies.

The next sections of this paper include a literature review that presents the theoretical works relied on in the study, a description of the methodology used in the study, and the research results. Final thoughts arising from this study are presented in the conclusion.

\section{Theoretical Background}

In this section, the main ideas addressed in this work, including organizational innovation, e-business, and business models will be described, and there will also be a brief characterization of small enterprises.

Through innovation, companies seek to meet time demands and respond to customers, increase productivity, improve product quality, and reduce the project cycle to stay ahead of the competition.According to Sundbo and Gallouj (1998), the forces that drive the innovative process can be either external or internal. External forces are related to institutional, technological, managerial, social, and professional factors that influence activity. Internal forces are established by formal structures dedicated to innovation. The different ways in which these forces can combine in each situation will determine the pattern of innovation. Lubeck, Wittmann and Battistella (2012), based on seminal studies, states that some of the forces that influence innovation are: relations between research and innovation processes; external forces, like customers, competitors, government and suppliers; modes of distribution and circulation of information in the companies; processes, resources, legislation and regulation, new markets, among others.

Tidd, Bessant, and Pavitt (2005) claim that an enterprise must have a strong competitive advantage to do something that no other company does, or to do it more effectively. Thus, to identify innovations before their competitors, company executives should develop different skills and organizational capabilities. Nadler and Tushman (1999) suggest that it is also necessary for these executives to meet the demands of differentiation and integration.

According to Tigre (2006), when adopting new technologies, companies must adapt the technologies to their own socio-technical characteristics. Turban, Mclean, and Wetherbe (2004) claim that few innovations in human history have provided as many advantages as e-business. The global na- ture of this technology, its low cost, the opportunity it provides to reach millions of people, its interactive nature, the multiplicity of resources it provides, and the rapid growth of the internet all result in innumerable advantages for companies, individuals, and society. Laudon and Traver (2010) discuss other advantages derived from adopting e-business, including lower supply-chain costs, lower distribution costs, an ability to reach and serve customers who are spread out over a greater geographical range, and the ability to react quickly to the preferences and demands of consumers. Hartman and Sifonis (2000) identify several activities that businesses should engage in to succeed in e-business, such as developing a portfolio of e-business solutions; focusing on speed and customer service in achieving goals; continually developing and promoting the ability to respond to constant changes in the e-business environment. In this sense, it is important for enterprises that are adequately structured for e-business to generate business models that will enable them to accomplish the desired results.

According to Osterwalder, Pigneur, and Tucci (2005), a business model should address the relationship between business strategy, the company's organizational structure, and the available technological resources. These factors are influenced by technological changes, customer demands, competitive market forces, the social environment, and the legislation in the jurisdiction where the company is located. Other authors suggest that the business model describes the way that a company creates value. It "describes how a company earns money, specifying where it is located in the supply chain" (CHESBROUGH and ROSENBLOOM, 2002, p. 533) and "it shows the operation's design, structure, and governance to create value through exploiting business opportunities" (AMIT and ZOTT, 200I, p. 494).

The importance of elaborating a business model applies to all companies, regardless of sector or size, so this activity (i.e., elaborating a business model) is appropriate for small businesses whose goal is to improve their results through e-business.

The term "small enterprise" is common in business literature, but it has many possible definitions. Because of the heterogeneity of this type of organization, there is no consensus in the academic community regarding how it should be defined (TORRĖS and JULIEN, 2005). Qualitative and quantitative criteria are used in attempts to identify the characteristics and specific features of this type of organization. Leone (1999) identified the following characteristics of small enterprises: a) the specific structural characteristics include scarce resources, centralized management, and poor organizational maturity, b) the specific decision-making characteristics include intuitive decision-making, short-term time horizons, a high degree of decision-making autonomy; 
and c) the specific characteristics of the individuals involved include prevalence of an owner-manager, intermingled personal and corporate identity. According to Torrès (2004), the characteristics of small enterprises can be analyzed in terms of the proximity of the enterprise to staff members and other parties, including the hierarchical proximity between the owner-manager and staff members and customers.

\section{Method}

Although several studies have examined the adoption of ebusiness, few studies have focused specifically on Brazil with regard to how small enterprises develop business models related the adoption of e-business. Thus, this descriptive and qualitative study was performed to fill the gap in the literature in a manner recommended by Golden (1976). Golden suggests that social research progresses along a qualitativequantitative continuum to achieve greater precision, more refined measures, and a better understanding of the phenomenon.

The approach used in the present study includes case studies that were conducted in accordance with the framework established by Eisenhardt (1989) to determine how small companies are organized to act in a virtual environment, which allowed for the development of a questionnaire that was subsequently used in a survey for quantitative research. We chose to study small enterprises in goods and services sectors because these sectors include a large number of small enterprises in Brazil. The companies analyzed had internet sales or used the internet for business activities such as virtual auctions, online customer relationship portals, and on-line project development activities. Alternatively, the companies used the internet to manage their relationships with suppliers or to conduct business research.

In the qualitative stage of the study, we focused on 13 small enterprises. We created a questionnaire with 20 open-ended questions that addressed with the following topics: a) how the company obtained the idea of conducting internet-based business; b) difficulties they encountered in using the internet for business; c) changes in business processes that occurred after they started using the internet; and d) characteristics of their organizational structure after they started using the internet.

To analyze the case studies in the qualitative stage of our research, we applied the content analysis procedure proposed by Bardin (2008) to the interviewees' responses. This content analysis helped us to develop a quantitative questionnaire that we used to determine the characteristics of ebusiness adoption for small businesses. The value of this approach is based on the idea that the description and analysis of direct, objective observations can facilitate improvements in the way that research is conducted (CERVO, BERVIAN and SILVA, 2006).

In the second part of the study, which was quantitative, a questionnaire was administered in a non-probabilistic sample of I,258 small enterprises in the goods and services sector in São Paulo, Brazil. This questionnaire contained questions relating to the company's profile (e.g., size, branch activity), activities related to internet use, decisions about internet use, planning actions for internet use, organizational structure, and goals that the company hopes to achieve by using the internet. In addition, it also contained questions related to the difficulties that were encountered as well as the results that were obtained by using the internet, social networks, and the respondent's profile. All questions were evaluated on the basis of a Likert scale.

The questionnaire was sent to the companies by e-mail, and the companies that did not respond after two weeks were contacted by telephone. We received 167 questionnaires back, and after eliminating certain cases, we analyzed a total of 156 completed questionnaires, which represents a response rate of slightly over $12 \%$ of the group studied. The sample was representative because of the method of data collection (email and telephone). Of the 156 companies studied, $73 \%$ are in the wholesale and retail trade sector, $40 \%$ have physical and virtual stores, and $86 \%$ have been in business longer than 10 years. With regard to the respondents, $67 \%$ work in management positions in their companies (Table I).

After collecting quantitative data from the questionnaires, we proceeded to the next stage. The content validity of the questions was first analyzed on the basis of the responses obtained from a small group of companies so that the results could be used to interpret the scores obtained from the scales, but this analysis was not sufficient to validate all of the scales. Thus, Cronbach's alpha was used to evaluate the reliability of the scales. A value above 0.7 was obtained for each factor analyzed, which is generally recognized as suitable for quantitative analysis (HAIR et al., 2005). The descriptive statistics function of SPSSVersion I 5 software was thus used to analyze the frequency of responses.

To obtain access to the companies surveyed, a partnership was established with the Commercial Association of São Paulo (CASP), which selected I,258 member companies. Out of more than 3,000 small corporations, the CASP chose enterprises that had access to the internet, used the internet for business, and were classified as small according to the SEBRAE classification system. In this classification system, small commercial or service enterprises are defined as business entities having 10 to 49 employees. 


\begin{tabular}{|l|l|l|l|}
\hline Characteristic & N & $\%$ & \\
\hline Sector & Trade & 98 & 73 \\
\hline & Services & 58 & 37 \\
\hline $\begin{array}{l}\text { Distribution } \\
\text { channel }\end{array}$ & Only physical store & 64 & 41 \\
\hline & Only virtual store & 8 & 5 \\
\hline & Physical and virtual store & 62 & 40 \\
\hline & Other & 22 & 14 \\
\hline $\begin{array}{l}\text { Age of com- } \\
\text { pany }\end{array}$ & Less than 10 years & 21 & 14 \\
\hline & Between 11 and 20 years & 55 & 35 \\
\hline & Between 21 and 30 years & 33 & 21 \\
\hline & Older than 30 years & 47 & 30 \\
\hline $\begin{array}{l}\text { Title of re- } \\
\text { spondent }\end{array}$ & Owner, partner, president & 30 & 19 \\
\hline & Director, superintendent, manager & 57 & 37 \\
\hline & Supervisor, head, coordinator & 20 & 13 \\
\hline & Analyst, technician, specialist & 49 & 31 \\
\hline & & & \\
\hline
\end{tabular}

Table I: Characteristics of the sample

Companies that were associated with the Commercial Association of São Paulo were chosen for this study because many small companies are informal, especially those that started with the intention of operating only through the internet. By limiting our target sample to only companies associated with CASP, we were able to ensure that the subject enterprises are all formally established and that they operate in a way that takes into account their legal, corporate, tax, and commercial obligations.

\section{RESULTS}

\section{Qualitative Stage}

Out of I 3 companies studied in the qualitative stage, six had been using the internet for business since they began operating as companies. Younger companies that had been operating for less than 10 years generally considered the internet to be an environment for business, in addition to traditional physical stores.

The companies adopted e-business as a way to improve their business processes through the selling, promoting, and disseminating of products. These improvements can be considered to be an organizational innovation because they caused changes in the company's work procedures (TIGRE, 2006).
During the interviews, we found that although companies had an appropriate organizational structure for the virtual market, they depended on the owners to make decisions about issues relating to the internet and to propose new technologies and tools that were expected to bring improvements and innovations. This pattern reflects the centralization of decision-making in small businesses, which corroborates the study by Leone (1999).

The lack of appropriate planning before beginning to use the internet for business constituted one of the critical factors for these companies' success in the virtual world, which corroborates the study conducted by Leone (1999), particularly regarding the specific organizational and decision-making process in small companies.

As reported by Sundbo and Gallouj (1998), we identified a strong influence from external factors on these companies as an essential part of innovation. The external factors include market competition, available technology, the customers' comfort level with using the internet for commercial transactions, and communication with suppliers. The companies surveyed desired to differentiate themselves from their competitors, and they integrated their physical business activities with their virtual activities in a single organization

ISSN: 07I 8-2724. (http://www.jotmi.org)

Journal of Technology Management \& Innovation (C) Universidad Alberto Hurtado, Facultad de Economía y Negocios. 
with a defined strategic focus on increasing the profitability of operations. This result is consistent with the arguments of Nadler and Tushman (1999).

The success indicators that lead companies to act in ebusiness are clear and include the ability to quickly identify opportunities, a focus on fast customer service, and an appropriate relationship among different technological tools (HARTMAN and SIFONIS, 2000). Although some companies use market tools to measure their results, a more in-depth statistical analysis is required for accurate conclusions about each enterprise's success.

The organizational structures of most of the companies that we examined are quite similar. It is possible to identify a "typical structure" of these companies, as shown in Figure I. Businesses that conform to this typical structure had already started to perform organizational changes to partially decentralize their e-business activities.

The decentralization process in the e-business structure results from the organization's maturity in relation to its processes and controls. In this regard, the companies with more experience in the virtual market tend to move more quickly towards decentralized operations.

According to the interviews, the main advantages of using the internet for business are: a) "greater company exposure, greater visibility among competitors, and decreased spending on commissions for sales representatives, which makes it possible for the company to handle lower-value products and to improve its price competitiveness;" b) "greater geographical range;" (c) "fast service requests;" and (d) "improved payment and increased sales." All of these factors confirm the findings of Turban, Mclean, and Wetherbe (2004) as well as Laudon and Traver (2010).

The present study also shows that various companies did not plan to adopt electronic business operations, which confirms the intuitive adoption strategy and propensity for risks that Leone (1999) identifies as characteristics of small businesses. Out of the companies that conducted some form of planning before the adoption of the internet and that performed their activities in a traditional manner, there was great concern regarding logistics, which is a crucial activity for the success of e-business. It is noteworthy, however, that companies that were younger than ten years old and that began with internet operations conducted more detailed planning to begin their operations.

The main difficulties encountered by small enterprises in conducting business over the internet were the high cost of the technological infrastructure needed for a virtual store; difficulties in choosing the technology that was to be used to conduct business over the internet; the inadequate availability of information technology specialists with experience that would be appropriate for small businesses in creating and implementing virtual stores; inadequate logistics to deliver products sold on the internet; scarce financial resources that could be used to adopt this innovation; lack of qualified people, inside and outside the business, to operate the virtual store; lack of knowledge about product demand and the resources necessary for operating a virtual store; the need to constantly update information on the products that are currently available; and the difficulty of transferring the same feelings customers have for products in physical stores to the virtual world.

The main result identified by the companies was increased sales. However, other improvements in the structure and organization of the business were also found, including a reduction in selling costs, increased profits, better customer relationship because of improved customer service, and a reorganization of the activities of the physical store to improve sales and service procedures.

\section{Quantitative stage}

The results of this study indicate that enterprises begin to conduct business on the internet to improve their business processes through sales, promotions, and better dissemination of their products.

The centralized management was evident in these companies because the procedures were designed to centralize e-business decision-making in the hands of the owners or

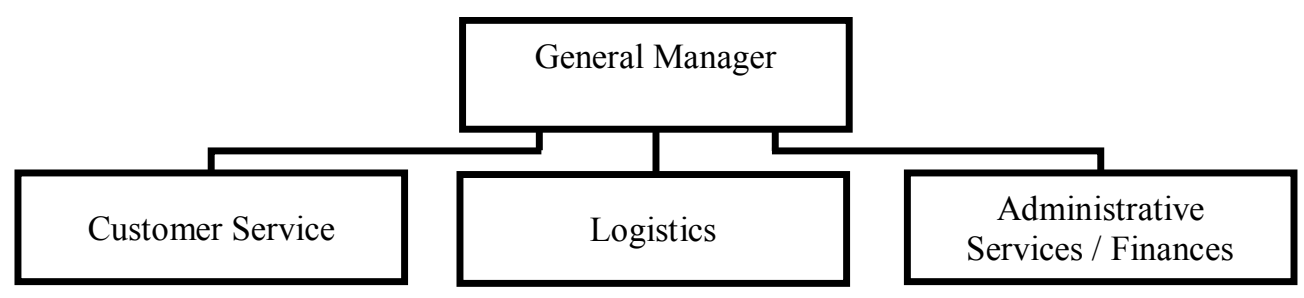

Figure I:Typical organizational structure of the companies examined

ISSN: 07I 8-2724. (http://www.jotmi.org)

Journal of Technology Management \& Innovation (C) Universidad Alberto Hurtado, Facultad de Economía y Negocios. 


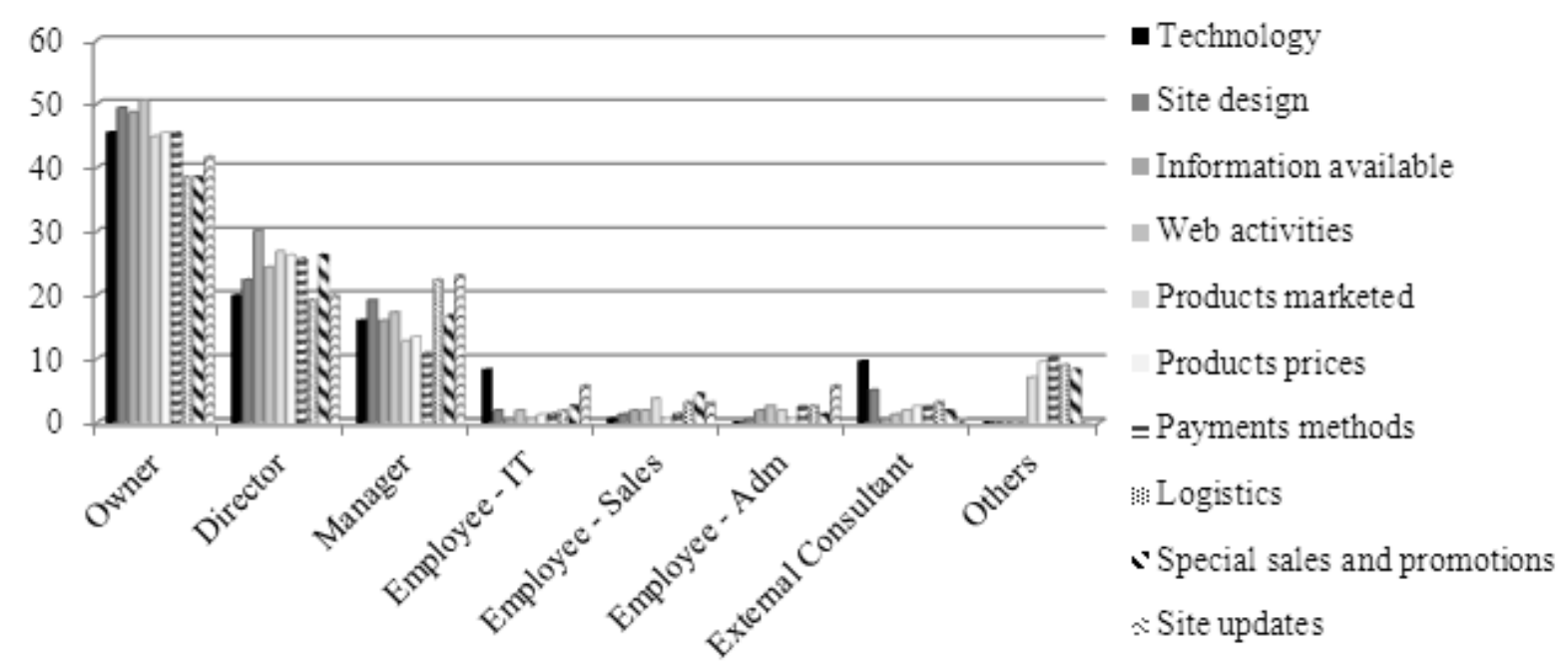

Figure 2: Hierarchical level of the individual responsible for e-business decisions

partners. Thus, decision making regarding issues related to internet operations and on the adoption of new technologies and tools that could provide improvements and innovations to business processes strongly depend on the owner. This concept is shown in Figure 2, which corroborates the information on organizational structure, decision making, and individual characteristics presented by Leone (1999).

It was also observed that the owner was less likely to make decisions that require technical knowledge such as logistics for product delivery and product promotion on the internet. The centralization of decision making reflects the centralization of activities related to business operations on the internet. In more than $50 \%$ of the companies examined, updating the company's website was the responsibility of a single employee.

Most companies combined activities from the physical and virtual stores. However, we observed that one-third of the companies had separate operations and analyzed the results separately for the physical and virtual stores (Figure 3 ). This arrangement significantly altered the organizational structure of the small enterprises by decentralizing operations while maintaining centralized decision making, and it represents an organizational innovation according to the Oslo Manual (OECD, 2005).

The main goals of the small companies that used the internet, as identified by $96.8 \%$ of the companies, was to improve brand or product exposure. Another important goal, present in $94.2 \%$ of the responses, was to improve customer relationship, as shown in Figure 4. These data demonstrate the companies' search for the advantages offered by e-business, as identified by Laudon and Traver (2010), showing a strategic use of e-business, different from the findings obtained by Pedraza, Guerrero and Lavin (20I I), that studied the alignment of e-Business with SMEs' Strategies in Northeast of Mexico companies and found a high tendency to use it more

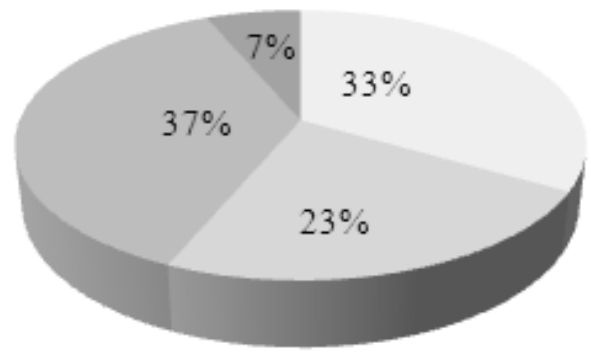

The physical and virtual store are totally separate

- The physical and virtual store are totally separate, but share activities

- There are no distinctions between the physical and virtual store. Everything is shared

- The company has only virtual store

Figure 3: Organization of companies with a virtual store

ISSN: 07 I 8-2724. (http://www.jotmi.org)

Journal of Technology Management \& Innovation (C) Universidad Alberto Hurtado, Facultad de Economía y Negocios. 
to help support activities (accounting, human resources) of the value chain than to the primary ones (marketing, sales, purchasing, and inventory management).

The initiatives found in our study also include new strategic moves for the company because the virtual store provides exposure for the brand that goes beyond the possibilities of the traditional physical market. The internet allows stores to operate in niche markets that would be practically impossible for them to explore outside the virtual world, and it brings the client closer to the company because it provides clients with more information about products and services. These strategic changes constitute organizational innovations according to the Oslo Manual (OECD, 2005).
Most companies use the internet to pursue several goals such as a) improving brand or product exposure, b) improving customer relationship, and c) accomplishing product or service differentiation. However, only the first of these goals has been achieved by most of the companies. The companies use their internet sites primarily to introduce themselves and their products (92.9\% of respondents) or to improve customer communication (73.1\% of respondents). Companies seek to align their goals with their use of the internet for business, but many companies do not have all of these features available via the internet. Nevertheless, according to Tidd, Bessant, and Pavitt (2005), the innovations spurred by e-business can help businesses to achieve competitive advantages over businesses that do not use the internet. It is important to remember that out of the 3,000 companies associated with the CASP, only I,258 have internet operations.

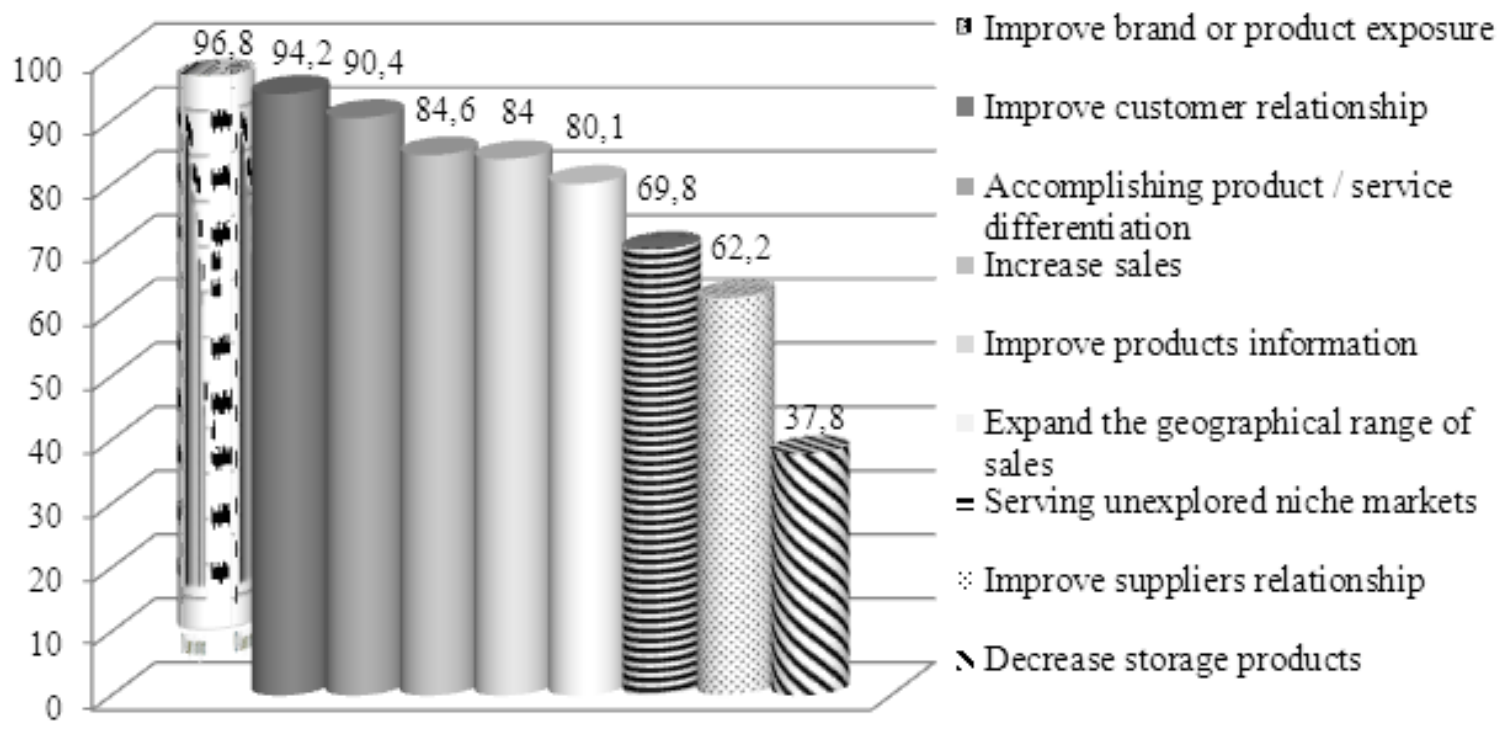

Figure 4: Main objectives of internet operations

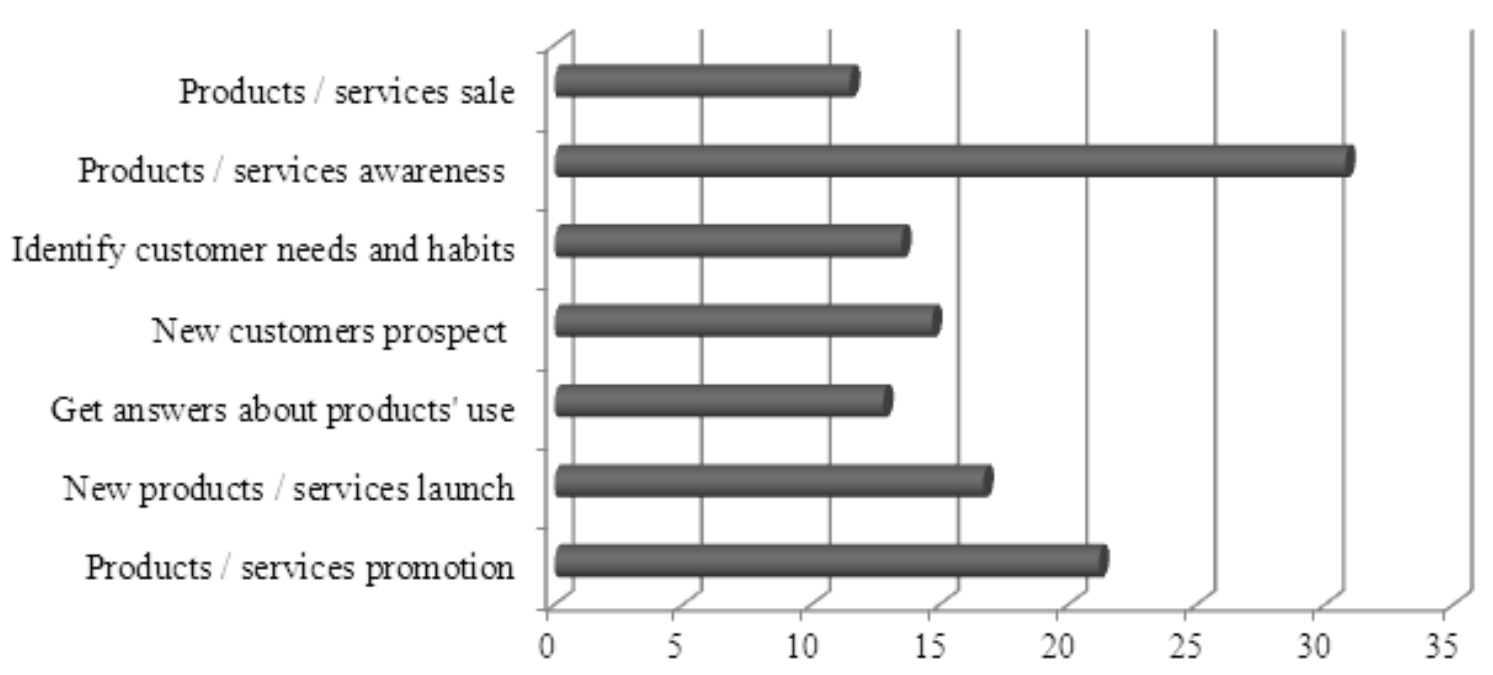

Figure 5: Companies using social networks

ISSN: 07 I 8-2724. (http://www.jotmi.org)

Journal of Technology Management \& Innovation (C) Universidad Alberto Hurtado, Facultad de Economía y Negocios. 
In addition to maintaining a company website, half of the companies surveyed use social networks on the internet to communicate with clients. The main factor leading companies to adopt this model was a concern about products and services awareness (Figure 5).

It was not possible to identify a dominant social network tool because it is possible for companies to use several different tools to promote their products and services. However, the information collected indicates that the most frequently used networks were Twitter (25\%), Orkut (19.2\%), Facebook (16\%), and YouTube (14.7\%). The information provided by the combanies also indicates that $55 \%$ of the com- panies update their websites as necessary and that the remainder of the companies update their websites periodically at intervals of one month or less. The frequency of updating demonstrates a concern for effectively providing information to the market, which is one of the factors for success identified by Hartman and Sifonis (2000).

With regard to planning, there is a strong concern about the financial resources necessary to adopt e-business at the expense of other strategic aspects that support the companies' proposed goals (Figure 6). This conflict reflects one of the inherent organizational characteristics of small businesses (Leone. 1999).

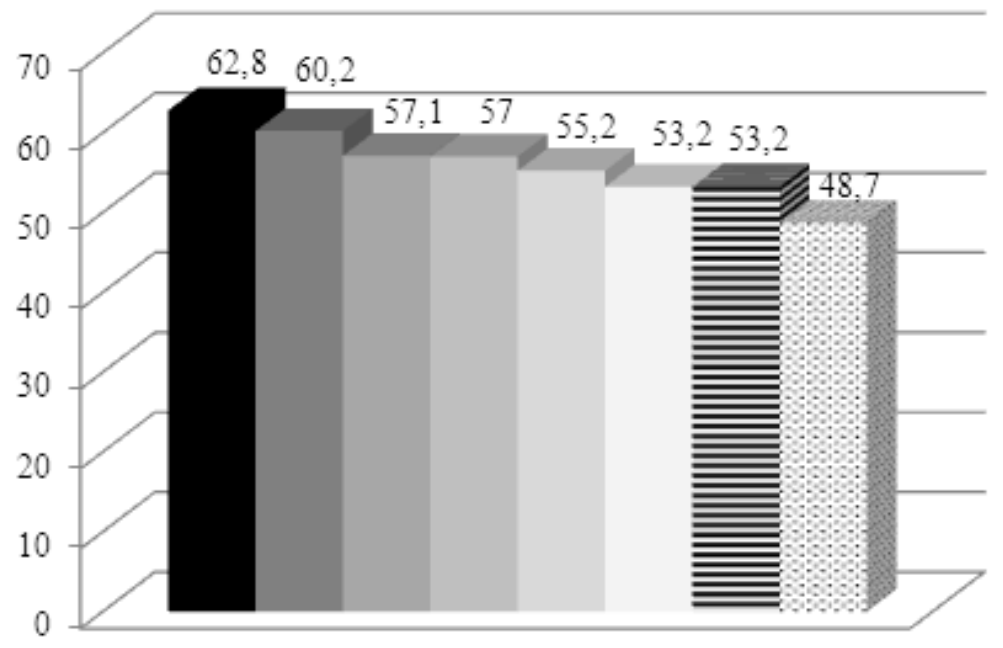

- Costs involved

Working capital needed

advertisement

- Logistics needed

Demand identification

Customer billing adequacy

$=$ Suppliers partnerships

Revenue forecasting

Figure 6: Planning aspects considered by companies for acting on the internet

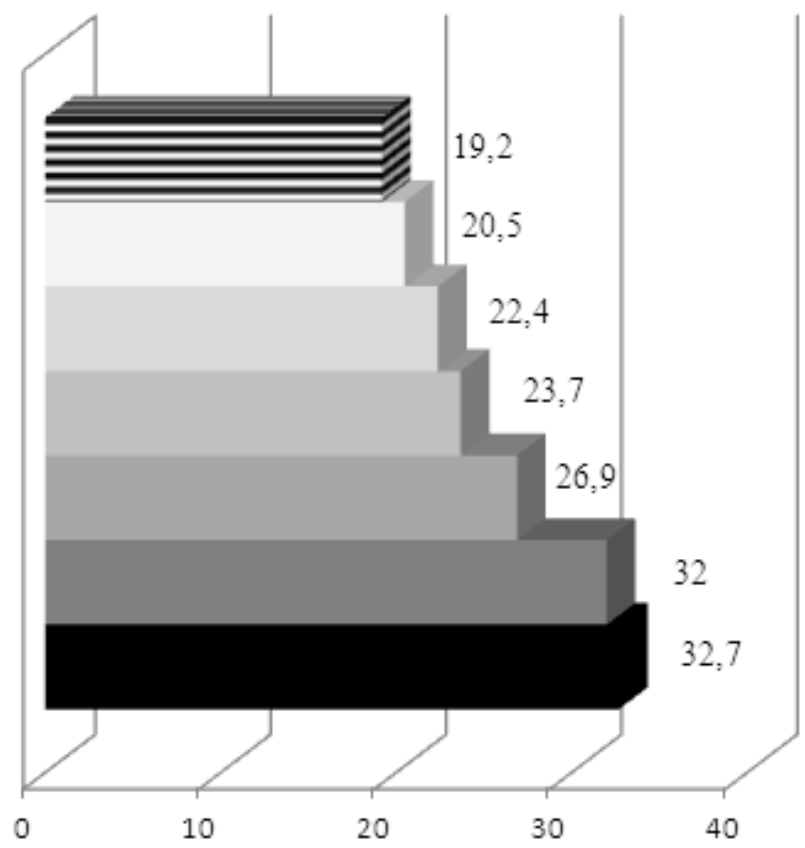

$=$ Transporting the sensations experienced by customers in the physical environment to the virtual environment

Knowing how to act in the virtual world

Definition of service providers for development of the company's virtual store

- Choice of technology available for creating and managing the company's website

n Obtaining professional support for site maintenance and / or the company's virtual store

nefine which web activity can lead to achieving the company's strategic objectives

- Lack of qualified people in the company to do web activities

Figure 7: Main difficulties in initiating activities on the internet

ISSN: 07 I8-2724. (http://www.jotmi.org)

Journal of Technology Management \& Innovation (c) Universidad Alberto Hurtado, Facultad de Economía y Negocios. 
According to the companies surveyed, the main difficulties in implementing e-business are related to the identification, use, and professional support for technological issues that are required for implementation. However, $32 \%$ of the companies interviewed had great difficulty in identification which activities should take place on the internet to help the company reach its strategic goals, as shown in Figure 7.

The difficulty in identifying which activities should take place on the internet to help the company reach its strategic goals reflects a lack of alignment between the activities performed on the internet and the goals that motivated the owner to adopt e-business. This misalignment causes incomplete planning with a heavy focus on costs and calculated risks (Leone, 1999).
The main result of adopting e-business identified by companies was brand exposure ( $94.2 \%$ of responses). However, improving customer relationship, expanding the geographical range of sales, and serving unexplored niche markets (LAUDON and TRAVER, 2010) also had a positive impact on more than $60 \%$ of the companies, as demonstrated in Figure 8. Thus, the companies' goals in implementing e-business were closely linked to the qualitative results obtained through the use of the internet, which facilitated the implementation of organizational innovations, as recommended by the Oslo Manual (OECD, 2005), and delivered value and made it possible for the companies to obtain a competitive advantage.

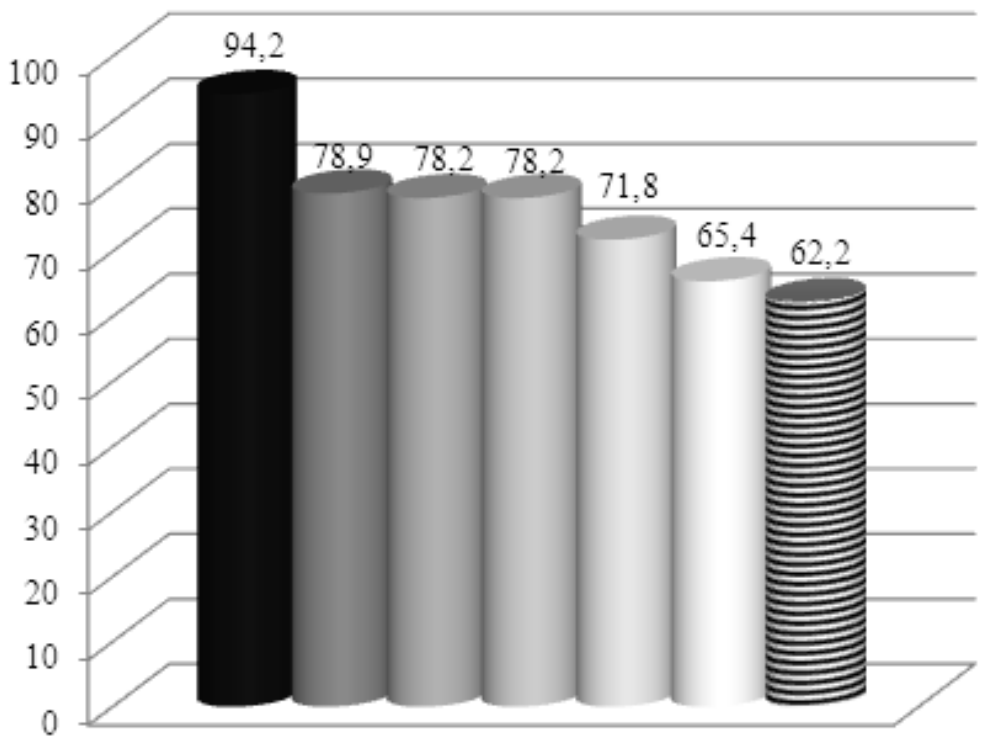

Figure 8: Principal results
- Improved brand exposure

$$
\begin{aligned}
& \text { Improving customer } \\
& \text { relationship } \\
& \text { Fast service to customer } \\
& \text { requests }
\end{aligned}
$$

Expanding the geographical range of sales

Increase in sales

Serving unexplored niche markets

$=$ Improved organization of the tasks of marketing products

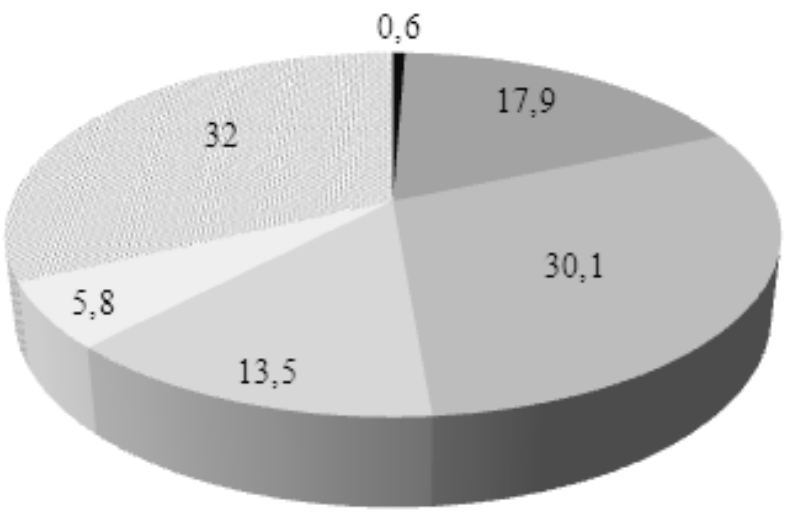

- Decreased

There was no increase or decrease

Increased from 1 to $20 \%$

Increased from 21 to $40 \%$

Increased from 41 to $60 \%$

Do not know

Figure 9: Change in revenue after the adoption of e-business

ISSN: 07I 8-2724. (http://www.jotmi.org)

Journal of Technology Management \& Innovation (c) Universidad Alberto Hurtado, Facultad de Economía y Negocios. 
An increase in sales was identified as a result of commercial activities on the internet by $71.8 \%$ of research participants, but this outcome was not experienced by $18.5 \%$ of companies that adopted e-business in their business procedures. These results are shown in Figure 9.

We found that a significant proportion of companies (32\%) could not determine how much their revenues increased after the adoption of e-business. However, almost half of the respondents reported a sales increase, and $30.1 \%$ of the respondents reported an increase of up to $20 \%$. It is noteworthy that $5.8 \%$ of the companies reported a sales increase of $41 \%$ to $60 \%$, which is a substantial improvement for companies of any size or sector.

\section{DISCUSSION}

Based on the data collected in this study, Table 2 presents the elements observed by small companies in constructing a business model for internet transactions, as recommended by Osterwalder, Pigneur, and Tucci (2005).

This model uses the pillars of business devised by Osterwalder, Pigneur, and Tucci (2005). In this model, we can see that small enterprises still need to improve their e-business activities by identifying which e-business activities should be developed to successfully reach the strategic goals. The difficulty in this task is linked to the fact that the owner makes the decisions about e-business activities, which can create a strategic alignment between the e-business and the company's goals. However, because these business leaders are rarely trained in technology, they are not knowledgeable about which e-business tools could be useful for their core business. Some obstacles that need to be overcome relate to the difficulty of training staff to use the internet and finding partners to develop e-business systems. In the qualitative phase of our research, many companies claimed they had difficulty in obtaining information about appropriate systems, which implies that there may be a beneficial opportunity for institutions such as SABRAE that work with small enterprises to provide appropriate technical information for this type of investment. Obtaining this type of assistance represents one of the challenges to achieving success, according to Hartman and Sifonis (2000), who therefore recommend the development of a portfolio of e-business solutions with an articulated vision along with various technical tools. Through e-businesses, small companies can obtain advantages such as greater and better product exposure, client loyalty, product differentiation, increased sales, increased product information, the spread of operations to geographically diverse markets, an ability to reach unexplored niche markets, and decreased storage costs for products.

\section{CONCLUSION}

The use of electronic business has been extensively explored in the academic environment. However, theoretical approaches to this topic focus broadly on issues relating to information technology or e-business models. There is a gap in the literature relating to the internal arrangements made by companies (and particularly the arrangements made by small companies) in their endeavor to use this tool. The objectives of this study were, therefore, to describe the business model used by small companies that adopted ebusiness as an innovation, to identify the main difficulties that they encountered, and to report the results that they obtained.

First, the results of this study show that adopting e-business is an organizational innovation for small companies in the trade and service sector. Organizational rearrangements in the company's existing structure must be made to accommodate this new activity. The clear goal of companies that adopt e-business is to improve their results, either by providing greater brand and product visibility or by expanding their markets, which is clearly consistent with the concept of innovational organization proposed by the Oslo Manual (OECD, 2005). This finding corroborates the study of Tidd, Bessant, and Pavitt (2005), who suggested that a company needs to have a competitive advantage to do things that are not done by other companies, or to do them more efficiently. This principle is consistent with the situation observed in the companies examined in this study. Out of 3,000 companies affiliated with CASP, only I,258 conduct business over the internet, but doing so helped these companies to obtain a competitive advantage over businesses that do not use e-business. According to the Oslo Manual (OECD, 2005), organizational innovations in business practices include new methods for organizing work routines and procedures, which were found in the present research in the way that entrepreneurs needed to train their staff to conduct e-business as well as in the way that they became aware of new organizational practices that were necessary to perform such activities. This innovation caused changes in the companies' procedures and organizational structure. The present analysis was based on the business model structure originally proposed by Osterwalder, Pigneur, and Tucci (2005). Our analysis of business models in companies that adopted e-business shows that the outstanding factor in terms of the proposed value of the internet was brand or market exposure, which appeared in $90 \%$ of the goals, actions, and results of the companies studied. Although the respondents also expressed concerns about maintaining closer relationships with customers, product differentiation, and sales, the companies used the internet primarily as an instrument for achieving enhanced exposure even at the expense of effective business transactions. However, the 
Table 2: Business model adopted by small business for e-business

\begin{tabular}{|c|c|c|}
\hline Pillar & $\begin{array}{l}\text { Building } \\
\text { Blocks of } \\
\text { the Business } \\
\text { Model }\end{array}$ & Description \\
\hline \multirow[t]{3}{*}{$\begin{array}{l}\text { Management } \\
\text { Infrastructure }\end{array}$} & Value setting & $\begin{array}{l}\text { The company uses a centralized structure, with the owner or } \\
\text { partner making the majority of decisions regarding e-busi- } \\
\text { ness. However, companies had difficulty identifying which } \\
\text { e-business activities could help them reach their goals. A } \\
\text { critical factor for success is a business model that integrates } \\
\text { the e-business activities and the strategic objectives of the } \\
\text { company. Generally, companies used the same structure they } \\
\text { used in the physical store and allocated staff to e-business ac- } \\
\text { tivities. Approximately 30\% of interviewees shared all activi- } \\
\text { ties (physical and virtual), and approximately } 30 \% \text { allocated } \\
\text { personnel specifically to activities related to e-business. In } \\
\text { terms of planning, it is noteworthy that businesses focused } \\
\text { the financial resources on the use of the internet at the ex- } \\
\text { pense of other more strategic aspects for planning. }\end{array}$ \\
\hline & Skills & $\begin{array}{l}\text { One of the main difficulties identified in the study relates to } \\
\text { the ability of the staff to perform e-business activities. There- } \\
\text { fore, this component of the business model is one of the criti- } \\
\text { cal factors for success in this activity. }\end{array}$ \\
\hline & Partnerships & $\begin{array}{l}\text { It was difficult for companies to identify partners in devel- } \\
\text { oping a virtual store that could contribute to the success of } \\
\text { e-business activities. }\end{array}$ \\
\hline Product & $\begin{array}{l}\text { Value proposi- } \\
\text { tion }\end{array}$ & $\begin{array}{l}\text { The benefits include better and more extensive brand and } \\
\text { product exposure, enhanced client loyalty, increased product } \\
\text { differentiation, increased sales, increased information about } \\
\text { products, spread of activities to geographically dispersed } \\
\text { markets, spread of operations to unexplored niche markets, } \\
\text { and decreased costs for product storage. }\end{array}$ \\
\hline \multirow[t]{3}{*}{$\begin{array}{l}\text { Customer } \\
\text { relationship }\end{array}$} & Audience & $\begin{array}{l}\text { E-business resulted in an increased number of customers in } \\
\text { the real world and made it possible to reach clients over a } \\
\text { larger geographical range. }\end{array}$ \\
\hline & Channels & $\begin{array}{l}\text { Channels included company website, e-mail, and social net- } \\
\text { works. }\end{array}$ \\
\hline & Relationship & $\begin{array}{l}\text { E-business helped companies to achieve improved relation- } \\
\text { ships with customers and suppliers through social networks } \\
\text { and other tools on the internet. }\end{array}$ \\
\hline \multirow[t]{2}{*}{$\begin{array}{l}\text { Financial } \\
\text { aspects }\end{array}$} & Cost Structure & $\begin{array}{l}\text { The reported costs consist primarily of direct costs (hiring } \\
\text { staff, purchasing systems). There is no cost structure for new } \\
\text { means of commercial activities (e-business). }\end{array}$ \\
\hline & Revenue Flow & $\begin{array}{l}\text { The revenue is primarily derived from increased sales that } \\
\text { result from the use of e-business. }\end{array}$ \\
\hline
\end{tabular}


success factors presented by Hartman and Sifonis (2000) for companies involved in e-business were clearly evident and include fast customer service (identified by $78.2 \%$ of companies) and constant changes in their e-business ( $45 \%$ of companies updated their web site at least once a month). In terms of management infrastructure, it is also noteworthy that decisions about e-business are centralized in the main manager and that companies often face a great difficulty in identifying which e-business activities could help them reach to their goals, which represents a critical point that needs to be examined in further studies. Various authors (CHESBROUGH and ROSENBLOOM, 2002; TEECE, 2009; AMIT and ZOTT, 200I) claim that a business model is a description of how the company creates value. Consequently, the description of how the company creates value has to be very clear, and if it is not, the company's business model needs to be adjusted. In the management infrastructure category, the respondents expressed a strong concern about the financial resources necessary for adopting e-business at the expense of other strategic aspects that support the company's proposed goals. This conflict is an inherent organizational characteristic of small businesses (LEONE, 1999). We also observed that there was no a cost structure to identify the monetary consequences of operating in new commercial environments (i.e., e-business).

Some of the results that we obtained from the companies participating in this study (such as their expanded geographical range, their ability to service unexplored niche markets, their improvements in marketing products, and their use of innovative resources such as social networks) reflect an advantage that they enjoyed over companies that do not use e-business. As discussed above, the greatest difficulties encountered by small companies that use e-business involve problems in identifying, using, and obtaining professional support for technological issues relating to implementation. A total of $32 \%$ of the interviewees mentioned that they had difficulty identifying which activities would take place on the internet to reach the company's strategic goals.

Despite the rigorous procedures used in the present study, the following limitations were present:The results obtained here are limited to the data that were collected (i.e., data related to small companies in the service and retail sectors), so generalization to other sectors was not possible. Although the response rate was satisfactory for our method of data collection, a greater number of respondents would allow the inclusion of more control variables, such as a differentiation between the goods and service sectors. Although the business models used by the companies surveyed were identified, it is not possible to determine whether a given model was better or worse than other similar models or whether the model examined applied to the entire population. Another limitation of the study relates to the subjectivity of our data, which results from the fact that there was only one respondent from each company and to the difficulty that we faced in obtaining an adequate number of responses from small businesses. The descriptive character of our study also prevented us from finding correlations between pillars in the business model proposed by Osterwalder, Pigneur, and Tucci (2005).

It would be desirable for future studies to be conducted in different locations or to cover a larger geographical area to generalize the results to a wider population. It would also be desirable to use a segmented approach to investigate small companies that adopt e-business by choosing different categories of businesses, determining how the companies in the different categories use e-business to obtain better results and achieve a competitive advantage, evaluating whether the companies in different categories that adopt e-business have business models with other characteristics, and looking for causal relationships between the business model and the results obtained by companies using e-business.

\section{REFERENCES}

AMIT R. and Zott C. (200I). Value creation in e-business. Strategic Management Journal, 22, 493-520.

BARDIN, L. (2008). Content Analysis. 5th edition. Lisbon: Editions70.

CERVO, A. L., Bervian, P. A. and Silva, R. (2006). Scientific Methodology. São Paulo: Prentice Hall Brasil.

CHESBROUGH, H. and Rosenbloom, R. S. (2002). The role of the business model in capturing value from innovation: evidence from Xerox corporation's technology spinoff companies. Industrial and Corporate Change, II (3), 529-555.

DEITEL, H. M. (2004). E-business and e-commerce for administrators. São Paulo: Personal Education.

EISENHARDT, K. M. (1989). Building Theories from Case Study Research. The Academy of Management Review, 14 (4), 532-550.

EPSTEIN, M. J. (2000). Organizing your business for the internet evolution, Strategic Finance Magazine, 82 (I), 56-60.

GOLDEN, M. P. (1976). Choices and Constraints in social research. In M.P. Golden (Ed), The Research Experience ( $p$. 3-3I). Itasca, IL: Peacock.

HAIR, J. F.; Babin, B.; Money, A. H.; Samuel, P.(2005). Essentials for Research Methods in Administration . Porto Alegre: Bookman. 
HARTMAN, A. ; Sifonis, J. (2000). Ready for the Web! Rio de Janeiro: Campus.

HÖGG, R.; Meckel, M.; Stanoevska-Slabeva,K. ; Martignoni, R. (2006). Overview of business models for Web 2.0 communities. Proceedings of GeNeMe 2006, p. 23-37, Dresden. http:// www.alexandria.unisg.ch. [Accessed March 13,20II ].

KALAKOTA, R. ; Robinson, M. (2002). E-business: Strategies for success in the digital world. Porto Alegre: Bookman.

KAPURUBANDARA, M. (2009). A Framework to e-Transform SMEs in Developing Countries. The Electronic Journal of Information Systems in Developing Countries, 39, (3), I-24.

KARTIWI,M.; MacGregor, R.C. (2007). Electronic commerce Adoption barriers in small to Medium-sized Enterprises (sMEs) in Developed and Developing countries: A crosscountry comparison. Journal of Electronic Commerce in Organizations, 5 (3), 35-5I.

LAWLER, E.I. (1996). From the Ground up: Six Principles for Building the New Logic Corporation, Jossey-Bass Inc. Publishers, San Francisco, CA.

LEONE, N.M.C.P.G. (1999). Characteristics of Small and Medium Enterprises. Journal of Management, São Paulo, 4, 91-94.

LAUDON, K. C. ; Traver, C. G. (20I0). E-commerce. business. technology.society. New Jersey, Prentice Hall.

LÜBECK, R.F.; Wittmann, M. L. ; Battistella, L. F. (20I2) Electronic Ticketing System As a Process of Innovation. Journal of Technology Management \& Innovation, 7 (I), 17-29.

MISHRA, S. (2010). Web aggregation in India: E-business models in new economy Int. J. Business and Emerging Markets, 2 (3), 252-266.

MORAES, G. D. A. ; Escrivão Filho, E.E. (2006). Managing information on the characteristics of small businesses. http:// www.scielo.br/pdf/ci/v35n3/v35n3al2.pdf [Accessed March $23,201 \mathrm{I}]$.

NADLER, D. A. ; Tushman, M. L. (1999). The organization of the future: strategic imperatives and core competencies for the 2 I st century. IEEE Engineering Management Review, Winter, 96-I2I.

OECD. (2005). Oslo Manual: proposed guidelines for collecting and interpreting data on technological innovation. 3rd edition, OECD, Paris.
OSTERWALDER, A., Pigneur,Y. and Tucci, C. L. (2005). Clarifying business models: origins, present, and future of the concept. Communications of the Association for Information Systems, 15, article.

PEDRAZA, N.; Guerrero, M.; Lavín, J. (20II) Alignment of E-Business with SMEs' Strategies in Northeast of Mexico, Journal of Technology Management \& Innovation, 6, (4), 205-224.

SEBRAE (2005). The presence of micro and small businesses in the Brazilian economy. http://antigo.sp.sebrae.com.br/ Principal/Conhecendo\%20a\%20MPE/. [Accessed April 12, 20II].

SUNDBO, J. ; Gallouj, F. (1998). Innovation in service. SI4S Synthesis Paper S2.

TEECE, D. J. (2009). Business model, business strategy and innovation. Long Range Planning, 43,(2-3): I72-194.

TIDD, J.; Bessant, J. ; Pavitt, K. (2005). Managing innovation: integrating technological, market and organizational change. West Sussex, UK: John Wiley \& Sons.

TIGRE, P. B. (2006). Innovation Management: the economy of technology in Brazil. Rio de Janeiro: Campus.

TORRĖS, O. (2004) The SME concept of Pierre-André Julien: an analysis in terms of proximity. Piccola Impresa/Small Business n. 2 .

TORRÈS, O. ; Julien, P.A. (2005). Specificity and denaturing of small business. International Small Business Journal, 23 (4), 355-377.

TURBAN, E.; Mclean, E. ; Wetherbe, J. (2004). Information technology for Management: transforming business in the digital world. Porto Alegre: Bookman.

WADE, M., Johnston, D. and Mcclean, R. (2004). Exploring the net impact of internet business solution adoption on SME performance, International Journal of Electronic Business, 2 (4), 336-350. 
J.Technol. Manag. Innov. 2012,Volume 7, Issue 2

ISSN: 07I8-2724. (http://www.jotmi.org)

Journal of Technology Management \& Innovation @ Universidad Alberto Hurtado, Facultad de Economía y Negocios. 